\title{
Some like it cold: distribution, ecology and phylogeny of Arenaria bernensis Favarger (Caryophyllaceae) from the western Prealps in Switzerland
}

\author{
Marjorie Berthouzoz $\cdot$ Simon Maendly $\cdot$ Sébastien Bétrisey $\cdot$ Sofia Mangili \\ Patrice Prunier • Christian Lexer • Gregor Kozlowski
}

Received: 7 February 2013/Accepted: 29 June 2013/Published online: 13 July 2013

(C) Swiss Botanical Society 2013

\begin{abstract}
Arenaria bernensis (Caryophyllaceae), traditionally placed within the Arenaria ciliata aggregate and discovered only in 1955, is a poorly studied endemic taxon of western Prealps in Switzerland. In this study, we aimed to deliver the first detailed appraisal on morphology, distribution and ecology of $A$. bernensis accompanied by first molecular insights into the A. ciliata aggregate using chloroplast (cp) DNA markers. Altogether 18 populations attributed morphologically to A. bernensis were found during our field surveys. The distribution area of A. bernensis forms an irregular line of ca. $50 \mathrm{~km}$ from the southwest (Dent de Lys, FR) to the north-east (Stockhorn, BE).
\end{abstract}

Electronic supplementary material The online version of this article (doi:10.1007/s00035-013-0116-5) contains supplementary material, which is available to authorized users.

M. Berthouzoz · S. Mangili · C. Lexer

Unit of Ecology and Evolution, Department of Biology,

University of Fribourg, Chemin du Musée 10,

1700 Fribourg, Switzerland

S. Maendly $\cdot$ P. Prunier

Haute école du paysage de l'ingénierie et de l'architecture,

Institute Earth, Nature and Environment, 150, rte de Presinge,

1254 Jussy, Switzerland

S. Bétrisey

Department of Geosciences, Conservation Biogeography,

University of Fribourg, Chemin du Musée 4,

1700 Fribourg, Switzerland

G. Kozlowski

Botanic Garden of the University of Fribourg, Chemin

du Musée 10, 1700 Fribourg, Switzerland

S. Bétrisey · G. Kozlowski ( $\square)$

Natural History Museum Fribourg, Chemin du Musée 6,

1700 Fribourg, Switzerland

e-mail: gregor.kozlowski@unifr.ch
The taxon counts globally ca. 4,000 individuals and the majority of populations are small $(<100$ individuals). Furthermore, our study demonstrates clear ecological and phytosociological differentiation between $A$. bernensis and Arenaria multicaulis, another member of the A. ciliata complex growing in the same geographic area. Arenaria bernensis grows exclusively on shady, cool and steep slopes with northern exposition in the alpine zone above 1,900-2,000 m a.s.1. Results of our chloroplast DNA analyses suggest that the A. ciliata aggregate is a monophyletic group (including A. ciliata s.str., A. multicaulis, A. gothica and A. bernensis). Additionally, A. bernensis is genetically closer to A. multicaulis than to A. ciliata s.str. However, our data also suggest that A. bernensis has a complex evolutionary history. Future investigation of nuclear genomic DNA is needed to clarify the phylogenetic status of A. bernensis. The present paper also delivers a first scientific drawing of $A$. bernensis and a detailed English description of its morphology. The here documented narrow endemic character of A. bernensis emphasizes the role of the western Prealps as a peripheral refugia during Quaternary glaciations.

Keywords Arenaria ciliata - Arenaria gothica . Arenaria multicaulis . CpDNA markers .

Narrow endemism · Peripheral Alps

\section{Introduction}

The Alps represent one of the most important biodiversity hotspots of the European continent (Ozenda 2002). In the distant past and during more recent geological periods, complex biogeographical and evolutionary processes resulted in an extraordinarily high number of endemic alpine taxa. 
Notably, 501 endemic taxa have been described in the Alps, comprising ca. $9 \%$ of the 4,485 taxa inhabiting this mountain range (Aeschimann et al. 2011). Some of these endemics are widespread in all parts of the Alps (e.g., Cirsium spinosissimum or Epilobium fleischeri). A very high number of alpine endemics, however, are small-range plants (Aeschimann et al. 2004). To this group of the so-called narrow endemics, some of the most emblematic alpine plants also belong, for example, Berardia subacaulis (Asteraceae). It is surprising, therefore, that only a small portion of narrowly alpine endemic plants were objects of intensive ecological and/or genetic studies, e.g., Draba ladina (Widmer and Baltisberger 1999) or Campanula excisa (Brun-Hol 2007).

The north-western peripheral Alps (hereafter western Prealps) form a relatively small but well-defined geological and biogeographical unit (Gilomen 1941; Becherer 1972; Caron 1973). They form part of the external calcareous Alps extending from Isère in France to Lower Austria. The western Prealps, their vegetation, floristic composition, geographical extension, geology, biogeographic connections as well as their socio-cultural particularities have recently been described by Gerber et al. (2010). They are composed of an archipelago of peripheral small chains and isolated summits (maximally 2,400 $\mathrm{m}$ in altitude), and occupy an area which is ca. $120 \mathrm{~km}$ long and $35 \mathrm{~km}$ wide.

The western Prealps are among the most important areas of plant diversity in Switzerland. They constituted one of the most important peripheral refugia in Switzerland during the Quaternary glaciations and served as source and crossroads for postglacial recolonisation of the western Alps (Stehlik 2000; Schönswetter et al. 2005; Parisod 2008). Many plants survived in this area in situ and display a high genetic diversity at the regional scale today (e.g., Biscutella laevigata; Parisod and Besnard 2007). Other plants used the western Prealps as pathways during several recolonisation waves and show a unique genetic composition in this area today (e.g., Eryngium alpinum from Moléson in the Prealps of Fribourg; Naciri and Gaudeul 2007). The unique floristic composition and extraordinary species richness of this region can additionally be explained by the proximity of the western Prealps and floristic exchanges with the south-western Alps, central Alps and Jura (Richard 1977; Gerber et al. 2010).

Arenaria bernensis Favarger (Caryophyllaceae) is a poorly studied endemic taxon occurring exclusively in the western Prealps (Eggenberg and Landolt 2006; Landolt 2006). The presence of $A$. bernensis and some other endemic and sub-endemic taxa in the western Prealps (e.g., Papaver occidentale, Anacamptis pyramidalis var. tanayensis) underpins the singular biogeographical and geological situation as well as conservation value of this region (Gerber et al. 2010). A. bernensis was discovered in August 1955 by Claude Favarger, a Swiss botanist and professor at the University of Neuchâtel, Switzerland, and obtained its scientific description in 1963 (Favarger 1963). The locus classicus next to Leiterenpass in Canton Bern (Switzerland) and few neighboring populations around the summits of Gantrisch and Stockhorn were the only known occurrences of this taxon for a long time. During subsequent years, the plant material and observations collected in this area were used for preliminary phytosociological, ecological, caryological, biometrical studies and even biogeographical considerations concerning the Arenaria ciliata complex, to which A. bernensis was included (Favarger 1960, 1963, 1965; Wyse Jackson and Parnell 1987). Richard (1977) later described some more populations scattered in the western Prealps (notably in Vanil Noir complex and Schopfenspitz, Canton Fribourg).

Due to a limited number of recent studies and detailed surveys, the morphology, ecology, distribution, taxonomic status and phylogenetic relationships of $A$. bernensis remain unclear and definitively require new investigations (Landolt 2006). It is generally accepted that $A$. bernensis should be included in the complex of $A$. ciliata, together with three other taxa present in the Swiss flora: A. ciliata s.str., Arenaria multicaulis and Arenaria gothica (Favarger 1963; Lauber et al. 2012). However, no genetic and phylogeographic studies are currently available for populations and species of the whole A. ciliata complex collected across the Alpine arc. As a result, the taxon is not always accepted and included in regional and Alpine floras (e.g., Aeschimann et al. 2004; Aeschimann and Heitz 2005).

Interestingly, A. bernensis presents a very high ploidy level (dodecaploid, $2 n=240$ ), especially in comparison with A. multicaulis $(2 n=40)$ and A. gothica $(2 n=40)$, and also with A. ciliata s.str. $(2 n=40-160)$. Additionally, populations from Wiener Schneeberg in Lower Austria, morphologically and caryologically similar to A. bernensis $(2 n=200)$, were supposed to belong to the same taxon (Favarger 1963). It is not clear, however, whether A. bernensis is an allo- or autopolyploid taxon, although Favarger (1965) privileged the allopolyploid origin. Favarger and Contandriopoulos (1961) classified A. bernensis as an apoendemic taxon of allopolyploid origin. Such endemics are often results of relatively rapid mixture between different floristic elements, for example, due to rapid migration events.

The main aim of the present study was to deliver the first detailed appraisal on morphology, distribution and ecology of $A$. bernensis with preliminary molecular insights into the A. ciliata aggregate using chloroplast (cp) DNA markers. Following questions were addressed: (1) What is the distribution of A. bernensis, the number of populations and the estimation of the number of individuals? (2) What are the ecological characteristics (e.g., altitudinal range, exposition and co-occurring species, etc.) of A. bernensis in comparison with the sympatric A. multicaulis? (3) What are the phylogenetic and phylogeographic positions of $A$. bernensis 
within the $A$. ciliata aggregate? Since the taxon was never described in a separate monography, the aim of the present paper was also to deliver a first scientific drawing of A. bernensis and a detailed English description of its morphology.

\section{Materials and methods}

\section{Morphological differentiation of A. bernensis}

Arenaria bernensis was determined in the field according to the description in Favarger $(1960,1963,1965)$ and in Lauber et al. (2012). In order to facilitate further research and conservation of $A$. bernensis, we here provide a first detailed English description of its morphology and the first ever scientific drawing of $A$. bernensis (Fig. 1). The drawing is based on living plant material from locus classicus (Leiterenpass, BE).

Arenaria bernensis is a perennial herb (chamaephyte) having a loose bunch growth habit with prostrate $8-12 \mathrm{~cm}$ long shoots. The leaves are opposite, 3-5 $\mathrm{mm}$ long and $1.2-2 \mathrm{~mm}$ wide, lanceolate with distinct midrib, slightly succulent, their margins are ciliated for more than $1 / 3$ from the base. The inflorescence is a uniflore cymose (rarely with 2 flowers). Regular flowers are 1.8-2.2 cm in diameter, possess five 4-5 mm long sepals, five white 7-9 $\mathrm{mm}$ long petals, 10 stamina, and three styles. The seed capsules are 6-valved. The seeds are reniform, black and 0.9-1.2 mm long. Individuals with irregular flowers have 4-6 styles, 12-16 stamina and 6-9 petals. In such flowers, petals are wider and often overlap, which is rarely the case in regular flowers. Figure $1 \mathrm{~g}$ shows several variants of such irregular flowers.

Thus, the most important characteristics facilitating the assignment of $A$. bernensis in the field from other Arenaria taxa in the western Prealps are: (1) large and solitary flowers, ca. $2 \mathrm{~cm}$ in diameter, (2) the loose habit of the whole plant with long shoots, and (3) the presence of (at least few) irregular flowers per population, with higher numbers of petals, stamens and styles. In comparison, the flowers of A. multicaulis are only $1 \mathrm{~cm}$ in diameter and their inflorescence usually possesses 5-7 flowers. Arenaria ciliata s.str. usually exhibits a very compact habit with short pulvinate shoots. However, according to Favarger (1965), there are only two Arenaria taxa from the A. ciliata complex occurring in the western Prealps: A. multicaulis and A. bernensis.

\section{Distribution survey and relevés}

The field surveys and relevés were carried out between 2009 and 2011 at the height of the growing season (July-September). Based on studies of Favarger (1960, 1963, 1965), Richard (1977) and the biogeographical delimitation of the western Prealps (Gerber et al. 2010), more than 100 potential localities across the entire area of the western Prealps were systematically inspected, both in France (Haute-Savoie) and in Switzerland (cantons of Valais, Vaud, Fribourg and Bern). Additionally, the occurrences from the Wiener Schneeberg in Austria, which potentially belong to A. bernensis according to Favarger (1963), were re-discovered and sampled. Table 1 lists all investigated populations. We have screened the herbaria of Zürich (Z), Geneva (G), Neuchâtel (NEU), Fribourg (NHMF) and Vienna (W). However, due to the quality of plant material, especially of the petals in the investigated specimens, it was not possible to use the herbarium material in any chorological analysis.

In each population with plants attributed morphologically to A. bernensis, the following data were recorded. (1) Altitude: for small populations, one altitude in the center of the population was measured. In large populations, the lowest and highest altitudes were measured; (2) Geographical coordinates of the population center: The altitude and geographical coordinates were measured using GPS (Garmin); (3) Population size: In small populations, all individuals were counted. In populations with more than 500 plants, the number of individuals was estimated; (4) The presence of irregular flowers was registered; and (5) Phytosociological relevés. For each relevé, the altitude, coordinates, exposition, inclination (in \%) were determined and/or measured. Relevés were done according to the Braun-Blanquet method (Poore 1955a, b). Statistical analyses of relevés and dendrograms were carried out with Minitab Inc. (Coventry, UK) (Bouxin 1986). Nomenclature of plant taxa follows Lauber et al. (2012). Furthermore, to explore the ecological and phytosociological differences between the two sympatric Arenaria taxa in western Prealps, 2-3 relevés of $A$. multicaulis were carried out in the vicinity of each discovered $A$. bernensis population.

\section{Sampling for DNA analyses}

Plant material of individuals attributed morphologically to A. bernensis was sampled in July-September between 2009 and 2011, and leaf material was retrieved from 1 to 5 individuals per population (Table 2). Furthermore, three other taxa traditionally placed in the $A$. ciliata aggregate were also collected for the molecular analyses: A. gothica, A. multicaulis, and A. ciliata s.str. Arenaria multicaulis was collected from the western Prealps (3 populations), whereas A. ciliata s.str. was sampled from the central Alps (2 populations). Plant material of A. gothica was obtained from ex situ culture grown from seeds collected during 2003 from Lac de Joux, the only population of the taxon in Switzerland (Delarze et al. 2004). Furthermore, three potential outgroup taxa (to root the phylogenetic tree) were also sampled: Arenaria biflora, A. serpyllifolia s.str. and Cerastium fontanum subsp. vulgare (Table 2). Their nomenclature follows 
Fig. 1 Morphology of A. bernensis. a habit, b leaf, c seed capsule, $\mathbf{d}$ seed, $\mathbf{e}$ regular flower, $\mathbf{f}$ bottom view of sepals in a regular flower, $\mathbf{g}$ example of variants of irregular flowers with 6-9 petals, 12-16 stamens and 5-6 styles. Based on plant material collected in locus classicus (Leiterenpass, Canton Bern, Switzerland). Scale bars a, c, e, f, g $1 \mathrm{~cm}$; b $1 \mathrm{~mm}$; d $0.5 \mathrm{~mm}$. Original drawings by Martina Löwy

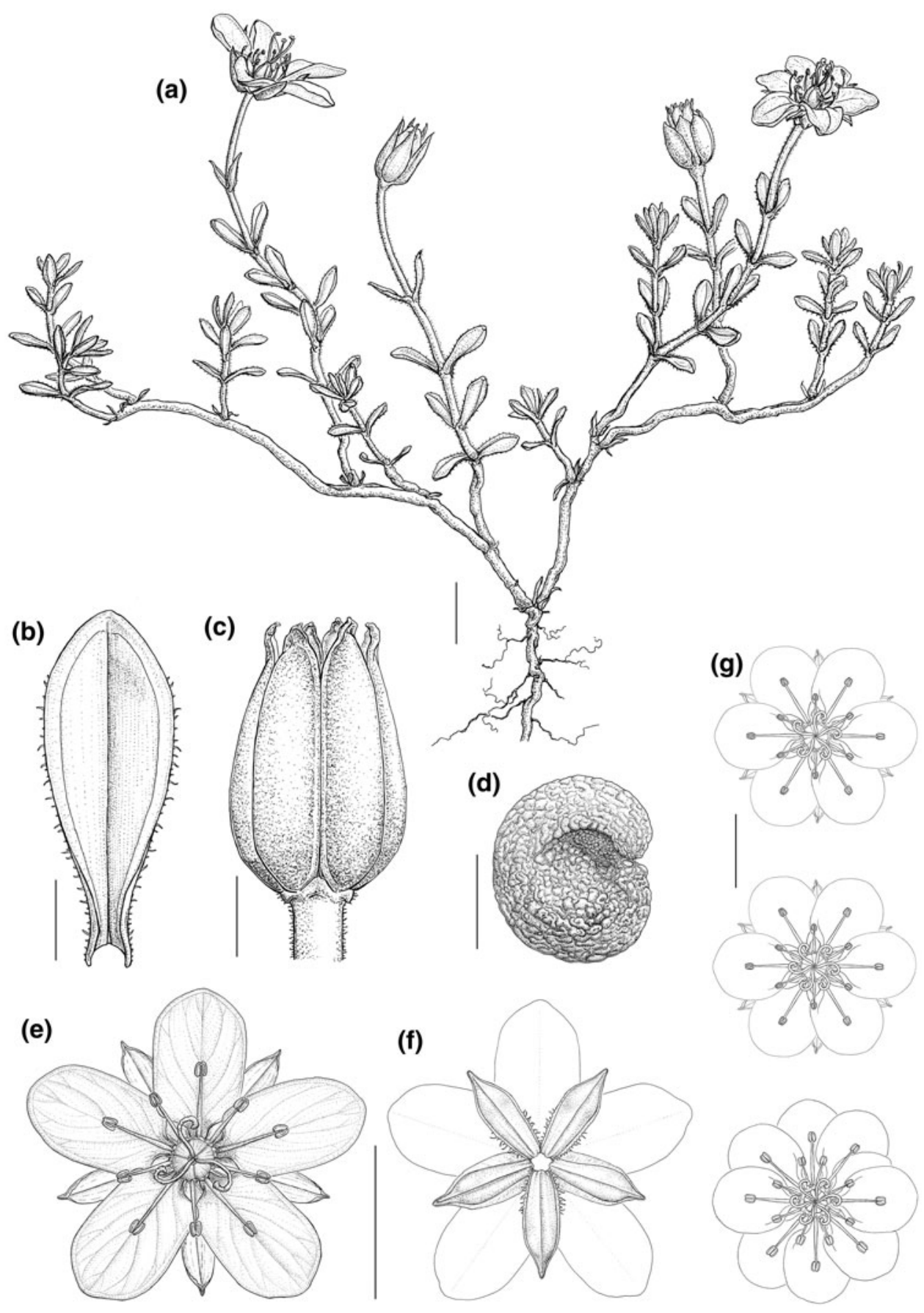

Lauber et al. (2012). All voucher specimens are deposited in the herbarium of the Natural History Museum in Fribourg, Switzerland (NHMF).

DNA extraction, primer tests and molecular marker assays

DNA extractions were carried out using the DNeasy Plant Mini from QIAGEN following the manufacturers' protocols. Twenty milligrams of silica-dried leaf material of each individual was ground using a tissue lyser coupled with tungsten beads. Altogether, 25 individuals belonging to 7 taxa and 16 populations were extracted (Table 2).

Five cpDNA regions were screened for polymorphism [single nucleotide polymorphisms (SNPs) and insertion/ deletions (indels)] and tested on a representative set of six individuals from our total sample set (1abe, 12abe, 13abe, 22aci, 27ago and 28abi, Table 2): atpl-atpH (Shaw et al. 2007), $n d h \mathrm{~A}$ intron (Shaw et al. 2007), $r p S 16$ (Shaw et al. 2005), $\operatorname{trnS}$-trnG (Naciri et al. 2010) and $\operatorname{trn} \mathrm{T}-\operatorname{trn} \mathrm{L}$ (Taberlet 
Table 1 Populations attributed morphologically to A. bernensis and their short characteristics

\begin{tabular}{|c|c|c|c|c|}
\hline $\begin{array}{l}\text { Population complex/ } \\
\text { population }\end{array}$ & $\begin{array}{l}\text { Administrative unit } \\
\text { (canton/commune) }\end{array}$ & $\begin{array}{l}\text { Coordinates } \\
\text { N/E (center) }\end{array}$ & $\begin{array}{l}\text { Altitudinal range } \\
\text { ( } \mathrm{m} \text { a.s.l) }\end{array}$ & $\begin{array}{l}\text { Number of } \\
\text { individuals }\end{array}$ \\
\hline \multicolumn{5}{|l|}{ Dent de Lys } \\
\hline Dent de Lys west & FR/Châtel-St-Denis & $46^{\circ} 30^{\prime} 29.2^{\prime \prime} / 7^{\circ} 00^{\prime} 07.8^{\prime \prime}$ & 1,890 & 10 \\
\hline Dent de Lys east & FR/Haut-Intyamon & $46^{\circ} 30^{\prime} 28.8^{\prime \prime} / 7^{\circ} 00^{\prime} 11.6^{\prime \prime}$ & $1,850-2,000$ & 27 \\
\hline \multicolumn{5}{|l|}{ South of Vanil Noir } \\
\hline Pointe de Paray & $\begin{array}{l}\text { FR/Grandvillard and } \\
\text { VD/Château-d'Oex }\end{array}$ & $46^{\circ} 30^{\prime} 35.6^{\prime \prime} / 7^{\circ} 07^{\prime} 33.4^{\prime \prime}$ & $2,100-2,375$ & 30 \\
\hline Bounavalette & FR/Grandvillard & $46^{\circ} 31^{\prime} 48.0^{\prime \prime} / 7^{\circ} 08^{\prime} 25.1^{\prime \prime}$ & 1,771 & 4 \\
\hline Tsermont & FR/Grandvillard & $46^{\circ} 32^{\prime} 26.9^{\prime \prime} / 7^{\circ} 08^{\prime} 28.0^{\prime \prime}$ & 2,040 & 20 \\
\hline \multicolumn{5}{|c|}{ North of Vanil Noir (Vallon des Morteys) ${ }^{\mathrm{a}}$} \\
\hline Rochers des Tours & FR/Charmey & $46^{\circ} 31^{\prime} 50.4^{\prime \prime} / 7^{\circ} 09^{\prime} 53.7^{\prime \prime}$ & $1,950-2,030$ & 405 \\
\hline Dzori Marro & FR/Charmey & $46^{\circ} 32^{\prime} 19.6^{\prime \prime} / 7^{\circ} 10^{\prime} 51.9^{\prime \prime}$ & 1,751 & 2 \\
\hline Dent de Folliéran & FR/Bas-Intyamon and Charmey & $46^{\circ} 32^{\prime} 29.2^{\prime \prime} / 7^{\circ} 09^{\prime} 30.1^{\prime \prime}$ & $2,106-2,344$ & ca. 1,000 \\
\hline D. de Brenleire west & FR/Charmey & $46^{\circ} 33^{\prime} 05.0^{\prime \prime} / 7^{\circ} 10^{\prime} 30.9^{\prime \prime}$ & $2,068-2,353$ & ca. 1,000 \\
\hline D. de Brenleire east & FR/Charmey & $46^{\circ} 33^{\prime} 08.0^{\prime \prime} / 7^{\circ} 10^{\prime} 46.0^{\prime \prime}$ & $1,980-2,020$ & 18 \\
\hline Schopfenspitz ${ }^{\mathrm{a}}$ & FR/Charmey and Jaun & $46^{\circ} 37^{\prime} 21.1^{\prime \prime} / 7^{\circ} 15^{\prime} 02.1^{\prime \prime}$ & $2,015-2,100$ & 69 \\
\hline \multicolumn{5}{|l|}{ Kaiseregg $^{\mathrm{a}}$} \\
\hline Kaisereggpass & FR/Jaun and Plaffeien & $46^{\circ} 38^{\prime} 58.8^{\prime \prime} / 7^{\circ} 18^{\prime} 52.4^{\prime \prime}$ & $2,050-2,100$ & ca. 1,000 \\
\hline Salzmatt & FR/Plaffeien & $46^{\circ} 39^{\prime} 31.2^{\prime \prime} / 7^{\circ} 19^{\prime} 01.7^{\prime \prime}$ & 1,665 & 5 \\
\hline \multicolumn{5}{|l|}{ Gantrisch $^{\mathrm{a}}$} \\
\hline Gantrisch west & BE/Rüschegg & $46^{\circ} 42^{\prime} 18.2^{\prime \prime} / 7^{\circ} 26^{\prime} 59.1^{\prime \prime}$ & 2,150 & 26 \\
\hline Gantrisch east & $\mathrm{BE} /$ Rüeggisberg & $46^{\circ} 42^{\prime} 21.4^{\prime \prime} / 7^{\circ} 27^{\prime} 08.5^{\prime \prime}$ & 2,140 & 66 \\
\hline Leiterenboden & $\mathrm{BE} /$ Rüeggisberg & $46^{\circ} 42^{\prime} 29.5^{\prime \prime} / 7^{\circ} 27^{\prime} 06.2^{\prime \prime}$ & 1,750 & 5 \\
\hline Leiterenpass & $\mathrm{BE} /$ Rüeggisberg & $46^{\circ} 42^{\prime} 15.0^{\prime \prime} / 7^{\circ} 27^{\prime} 22.6^{\prime \prime}$ & 1,910 & 26 \\
\hline Stockhorn $^{\mathrm{a}}$ & BE/Oberstocken & $46^{\circ} 41^{\prime} 39.2^{\prime \prime} / 7^{\circ} 32^{\prime} 14.4^{\prime \prime}$ & $2,150-2,190$ & 50 \\
\hline Total & & & & $3,750-4,000$ \\
\hline
\end{tabular}

FR, VD, BE cantons of Fribourg, Vaud and Bern, respectively

${ }^{\text {a }}$ Population complexes with individuals showing irregular flowers

et al. 1991). Based on this initial screen for polymorphism, $n d h \mathrm{~A}$ intron and $r p \mathrm{~S} 16$ were chosen for further analysis of the entire sample set.

Each chloroplast region was PCR-amplified in $50 \mu \mathrm{l}$ of solution containing: $\mathrm{H}_{2} \mathrm{O}$ Unifr Mili Q, $1 \times$ Taq buffer BIOLINE, $2 \mathrm{mM} \mathrm{MgCl}_{2}$ BIOLINE, $100 \mu \mathrm{M}$ dNTP BIOLINE, 10 pmol of each primer, F and R, 0.5 U Taq BIOLINE, and finally the DNA at a concentration of $5 \mathrm{ng} / \mu \mathrm{l}$. The PCR cycling program followed Scarcelli et al. (2011). The amplification was examined on a $1 \%$ agarose gel run for $30 \mathrm{~min}$ at $74 \mathrm{mV}$ and visualized by UV (safe view staining). The PCR products were purified using the ExoSAP method followed by ethanol precipitation. The purification was carried out by adding $1 \mu \mathrm{l}$ of ExoSAP enzyme mix diluted 1:5 in $2.5 \mu \mathrm{l}$ of PCR product, and by heating at $37{ }^{\circ} \mathrm{C}$ for $60 \mathrm{~min}$ and $80{ }^{\circ} \mathrm{C}$ for $20 \mathrm{~min}$. Once the precipitated DNA had dried, the DNA was re-suspended in $22 \mu \mathrm{l}$ (for tubes) or $12 \mu \mathrm{l}$ (for plates) of $10 \mathrm{mM}$ TE buffer. The DNA concentration was measured with the Nanodrop ATCGgen photometer and dilutions were prepared to obtain a concentration of $50 \mathrm{ng} / \mu \mathrm{l}$ for each sample. Finally, the amplicons were sequenced from both ends (forward and reverse) by MACROGEN. The sequences received from MACROGEN were analyzed by means of the SEQUENCHER software. The sequences were aligned and contigs were built using BIOEDIT. Since the cpDNA genome represents one single non-recombining locus, sequence contigs for $n d h \mathrm{~A}$ intron and $r p \mathrm{~S} 16$ were analyzed in concatenated form in all subsequent analyses. GenBank/NCBI accession numbers are KF265205-KF265254.

\section{Phylogenetic reconstruction}

A parsimony tree with 1,000 bootstrap replicates was obtained using the DNAPARS and SEQBOOT programs within the PhyLIP 3.63 software package. This widely used approach to parsimony reconstruction is known to perform well for reconstructing genealogies from non-recombining 
Table 2 List of individuals and taxa sampled for the cpDNA analysis with short characterization of the collection sites

\begin{tabular}{|c|c|c|c|c|}
\hline Taxon/sample numbers & Site name & Country/region & Coordinates N/E & Altitude (m a.s.1.) \\
\hline \multicolumn{5}{|c|}{ Arenaria bernensis Favarger (morphological attribution prior to the molecular analysis) } \\
\hline 1abe & Dent de Lys & Switzerland/FR & $46^{\circ} 30^{\prime} 28^{\prime \prime} / 7^{\circ} 00^{\prime} 10^{\prime \prime}$ & 2,005 \\
\hline 2abe & Pointe de Paray & Switzerland/FR & $46^{\circ} 30^{\prime} 48^{\prime \prime} / 7^{\circ} 08^{\prime} 12^{\prime \prime}$ & 2,365 \\
\hline 4abe & Dent de Brenleire ${ }^{\mathrm{a}}$ & Switzerland/FR & $46^{\circ} 33^{\prime} 09^{\prime \prime} / 7^{\circ} 10^{\prime} 23^{\prime \prime}$ & 2,110 \\
\hline 6abe & Kaisereggpass ${ }^{\mathrm{a}}$ & Switzerland/FR & $46^{\circ} 38^{\prime} 56^{\prime \prime} / 7^{\circ} 18^{\prime} 52^{\prime \prime}$ & 2,074 \\
\hline 7-11abe & Leiterenpass/Gantrisch $^{\mathrm{a}}$ & Switzerland/BE & $46^{\circ} 42^{\prime} 15^{\prime \prime} / 7^{\circ} 27^{\prime} 24^{\prime \prime}$ & 1,900 \\
\hline 12abe & Stockhorn $^{\mathrm{a}}$ & Switzerland/BE & $46^{\circ} 41^{\prime} 37^{\prime \prime} / 7^{\circ} 32^{\prime} 12^{\prime \prime}$ & 2,167 \\
\hline 13abe & Schneeberg, Klosterwappen & Austria/Lower A. & $47^{\circ} 46^{\prime} 30^{\prime \prime} / 15^{\circ} 48^{\prime} 28^{\prime \prime}$ & 2,060 \\
\hline \multicolumn{5}{|l|}{ Arenaria multicaulis L. } \\
\hline $15 \mathrm{amu}$ & Dent de Lys & Switzerland/FR & $46^{\circ} 30^{\prime} 24^{\prime \prime} / 7^{\circ} 00^{\prime} 07^{\prime \prime}$ & 2,000 \\
\hline $17 \mathrm{amu}$ & Kaisereggpass & Switzerland/FR & $46^{\circ} 38^{\prime} 58^{\prime \prime} / 7^{\circ} 18^{\prime} 53^{\prime \prime}$ & 2,057 \\
\hline $18,20 \mathrm{amu}$ & Leiterenpass/Gantrisch & Switzerland/BE & $46^{\circ} 42^{\prime} 16^{\prime \prime} / 7^{\circ} 27^{\prime} 43^{\prime \prime}$ & 1,900 \\
\hline \multicolumn{5}{|l|}{ Arenaria ciliata s.str. L. } \\
\hline 22aci & Les Echessettes & Switzerland/VS & $45^{\circ} 56^{\prime} 57^{\prime \prime} / 7^{\circ} 07^{\prime} 53^{\prime \prime}$ & 2,430 \\
\hline 23-25aci & Unterrothhorn, Zermatt & Switzerland/VS & $46^{\circ} 01^{\prime} 16^{\prime \prime} / 7^{\circ} 48^{\prime} 13^{\prime \prime}$ & 3,027 \\
\hline \multicolumn{5}{|l|}{ Arenaria gothica Fries } \\
\hline 27ago & Lac de Joux (ex situ) & Switzerland/VD & $46^{\circ} 38^{\prime} 22^{\prime \prime} / 6^{\circ} 17^{\prime} 09^{\prime \prime}$ & 1,000 \\
\hline \multicolumn{5}{|l|}{ Outgroups } \\
\hline \multicolumn{5}{|l|}{ Arenaria biflora $\mathrm{L}}$. \\
\hline 28-29abi & Aiguilles rouges & France/Savoie & $45^{\circ} 58^{\prime} 54^{\prime \prime} / 6^{\circ} 53^{\prime} 31^{\prime \prime}$ & 2,340 \\
\hline \multicolumn{5}{|c|}{ Arenaria serpyllifolia s.str. L. } \\
\hline 30-31ase & Fribourg & Switzerland/FR & $46^{\circ} 48^{\prime} 22^{\prime \prime} / 7^{\circ} 09^{\prime} 46^{\prime \prime}$ & 630 \\
\hline \multicolumn{5}{|c|}{ Cerastium fontanum subsp. vulgare (Hartm.) Greut. et Burd. } \\
\hline 32 cfo & Fribourg & Switzerland/FR & $46^{\circ} 48^{\prime} 22^{\prime \prime} / 7^{\circ} 09^{\prime} 46^{\prime \prime}$ & 630 \\
\hline
\end{tabular}

Taxon attribution based on Lauber et al. (2012). Ex situ collection was sampled in the Botanic Garden of the University of Fribourg, Switzerland

${ }^{a}$ Populations with individuals showing irregular flowers

haplotypic data (Salzburger et al. 2011). The phylogenetic tree was rooted using Cerastium fontanum (sample $32 \mathrm{cfo}$ ) as an outgroup. As an alternative method of phylogenetic reconstruction, a Bayesian tree was obtained with MrBayes v3.2 (Ronquist et al. 2011), using the GTR + I + T model (a general time reversible model of molecular evolution with a proportion of invariable sites and a gamma-shaped distribution of rates across sites) and default priors. As the results were highly congruent with the parsimony phylogeny, only the former is reported and discussed below.

Intraspecific analyses of haplotype relationships and diversity

We estimated the intraspecific genealogy of the A. ciliata aggregate using median-joining (MJ) network analysis (Bandelt et al. 1999). The MJ method is able to resolve even complex haplotype phylogenies affected by homoplasy, hybridization and/or recombination. The method starts by identifying median vectors, i.e., consensus sequences of markers that are biologically equivalent to extinct ancestral or possible unsampled haplotypes. The analysis was implemented in NETWORK for specimens of A. ciliata, A. bernensis, and A. multicaulis, i.e., those taxa with the a priori expectation for a history of gene exchange. In addition, we estimated levels of genetic diversity within A. bernensis by calculating the number of haplotypes, number of segregating sites, and nucleotide diversity in PROSEQ 3.69. Only nucleotide polymorphisms were considered in these analyses, while insertions/deletions (indels) were ignored.

\section{Results}

Distribution and population size

Altogether 18 populations attributed morphologically to A. bernensis were found. They can be grouped into six geographical regions (population complexes) (Table 1; Fig. 2). The global distribution of $A$. bernensis forms an irregular line of ca. $50 \mathrm{~km}$ from the south-west (Dent de Lys, FR) to the north-east (Stockhorn, BE). The majority of populations grow 
Fig. 2 Distribution of populations attributed morphologically to Arenaria bernensis. Red circles indicate populations comprising individuals with irregular flowers as shown in Fig. 1 (color figure online)

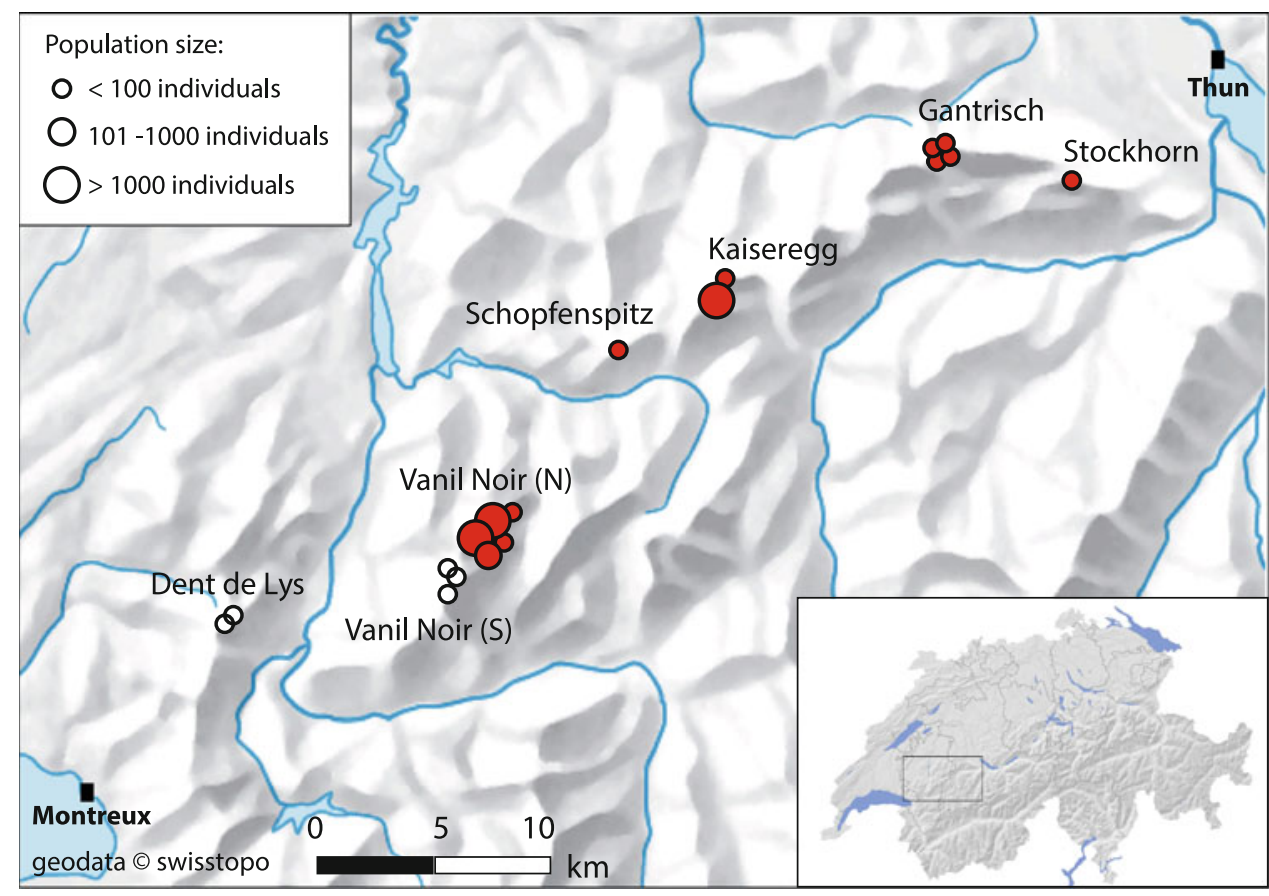

in Canton Fribourg (12 populations in 4 complexes). In Canton Bern, A. bernensis grows only around the summits of Gantrisch (4 populations) and Stockhorn (1 population). Several individuals from the Pointe de Paray population grow in the territory of the Swiss canton Vaud (Table 1).

Our results show that A. bernensis counts globally ca. 4,000 individuals. The overwhelming majority of populations are small, with less than 100 individuals (14 populations; Table 1; Fig. 2). One population counts ca. 400 individuals (Rochers des Tours). The remaining three populations are very big, with more than 1,000 individuals (Dent de Folliéran, Dent de Brenleire west and Kaisereggpass, all in Canton Fribourg). Thus, more than $95 \%$ of all known individuals of A. bernensis grow in Canton Fribourg.

Altitudinal range, slope exposition and inclination

The majority of populations and individuals grow above 1,900 m a.s.l. (Table 1). The upper altitudinal limit is formed by the highest summits of western Prealps. On Dent de Follièran $(2,344 \mathrm{~m})$ and Dent de Brenleire $(2,353 \mathrm{~m})$, for example, A. bernensis reaches the top of the summits. However, there are several small populations and isolated individuals of A. bernensis growing at much lower altitudes. All these plants occur at the bases of scree fields or on isolated blocks with long standing snow cover and/or cold microclimate. This is the case of Bounavalette (1,771 m), Dzori Marro $(1,751 \mathrm{~m})$ and Leiterenboden $(1,750 \mathrm{~m})$. The plants growing at the lowest known altitude were observed by Salzmatt at 1,665 m (Kaiseregg complex, Table 1) at the base of a large scree field. Arenaria bernensis grows almost exclusively on slopes with northern exposition (Figs. 3; S2). The average slope inclination is $56.3^{\circ}( \pm$ SD 26.5 ; Table $S 1)$. However, in particular microclimatic conditions (bases of scree, high altitude plateaus, sites with long shadow cover, etc.), the plant can grow locally on completely flat sites, and only exceptionally on surfaces with slightly southern exposition (Fig. 3; Table S1). Arenaria multicaulis, the second investigated taxon of the A. ciliata aggregate, grows in very different conditions. Although attaining high altitudes $(2,160 \mathrm{~m}$ a.s.l. in our study area), the species occurs exclusively on slopes with southern and south-eastern exposition (Fig. 3; Table S2) with the average slope inclination of $49.4^{\circ}( \pm$ SD 25.0 ; Table S2).

Relevés and co-occurring species

Table S1 presents 22 relevés which were carried out in all 6 population complexes of $A$. bernensis. The most important

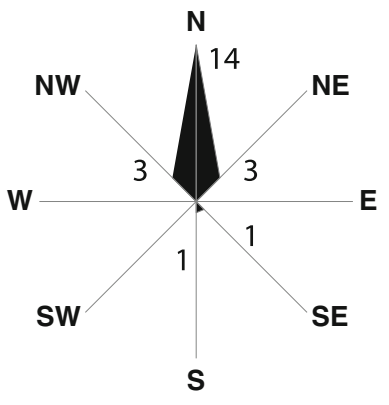

A. bernensis

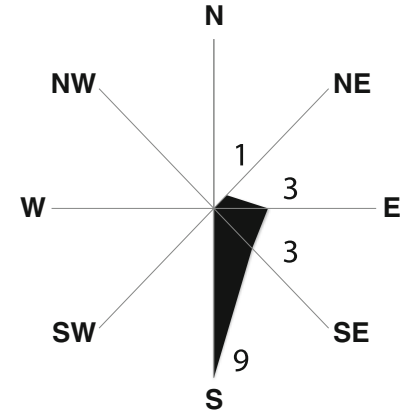

A. multicaulis
Fig. 3 Exposition of the relevés of Arenaria bernensis $(n=22)$ and A. multicaulis $(n=16)$ in the western Prealps, Switzerland 
accompanying plants of A. bernensis are two Poaceae, Festuca quadriflora and Sesleria caerulea, and Ranunculus alpestris, all present in more than $80 \%$ of relevés. Very common co-occurring species also are Polygonum viviparum, Saxifraga oppositifolia, Salix retusa, S. reticulata, Galium anisophyllon, Silene acaulis, Poa alpina, Ranunculus montanus and Myosotis alpestris, all present in more than $40 \%$ of relevés. Also very common are bryophytes, covering often between 50 and $75 \%$ of the relevé surface (Table S1; Fig. S2). They were, however, not determined during our survey.

Table S2 presents 16 relevès carried out in populations of A. multicaulis. The most important accompanying species of this taxon are Sesleria caerulea, Festuca ovina aggr., Carex sempervirens, Galium anisophyllon and Thymus polytrichus, all present in more than $80 \%$ of relevés. Very common co-occurring species also are Euphrasia salisburgensis, Festuca quadriflora, Ranunculus tuberosus, Poa alpina, Anthyllis vulneraria subsp. alpestris, Bupleurum ranunculoides, Alchemilla conjuncta aggr. and Polygonum viviparum, all present in more than $40 \%$ of relevés.

Figure 4 clearly underpins the strong differentiation between the communities of $A$. bernensis and A. multicaulis. Many of the co-occurring species of $A$. bernensis belong to the arctic-alpine element, typical of shady and cold slopes with northern exposition in the alpine zones (e.g., Salix reticulata, Saxifraga oppositifolia, Silene acaulis, Dryas octopetala). These species are absent or only accidental in the relevés of A. multicaulis, which on the contrary grows accompanied by numerous thermo- and xerophilous taxa (e.g., Festuca ovina and Thymus polytrichus) (Tables S1, S2).
Results of the primer tests

Tests of the first five cpDNA sequence regions revealed sufficient levels of amplification for $a t p l-a t p \mathrm{H}, n d h \mathrm{~A}$ intron and $r p \mathrm{~S} 16$, weak amplification for $\operatorname{trnT}$-trnL and no amplification of trnS-trnG for the outgroup taxa (A. biflora, 28abi). Thus, subsequent steps were focussed on atpl-atpH,

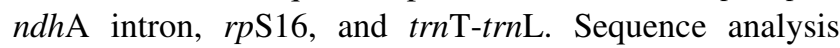
revealed that $n d h \mathrm{~A}$ intron and $r p \mathrm{~S} 16$ exhibited sufficient intra- and interspecific variability for the molecular systematics work. The resulting cpDNA sequences, $n d h \mathrm{~A}$ intron of 1,039 base pairs (bp) and $r p S 16$ of $794 \mathrm{bp}$, were concatenated within a final sequence length of $1,833 \mathrm{bp}$. Alignments of these concatenated sequences (total length $=1,833$ nucleotides) were used in subsequent steps. Among these, 123 polymorphic sites and 119 parsimonyinformative sites were identified in the entire ingroup, and 41 and 37 polymorphic and parsimony-informative sites, respectively, were recovered for the $A$. ciliata aggregate.

\section{Phylogenetic reconstruction}

Parsimony and Bayesian phylogenetic reconstruction yielded congruent results, and results of the former are presented here. The Parsimony cpDNA tree was able to resolve three major informative clades (Fig. 5): clade 1, including all specimens of $A$. ciliata s.str. with three specimens attributed morphologically to A. bernensis, clade 2 including the core A. bernensis from the locus classicus and all populations with irregular floral morphology, and clade 3 comprising individuals of A. gothica and A. multicaulis. Clade 2 was further divided into clade $2 \mathrm{a}$ (plants from locus classicus
Fig. 4 Dendrogram comparing the relevés of Arenaria bernensis (1-22) and A. multicaulis (23-38) in the western Prealps, Switzerland

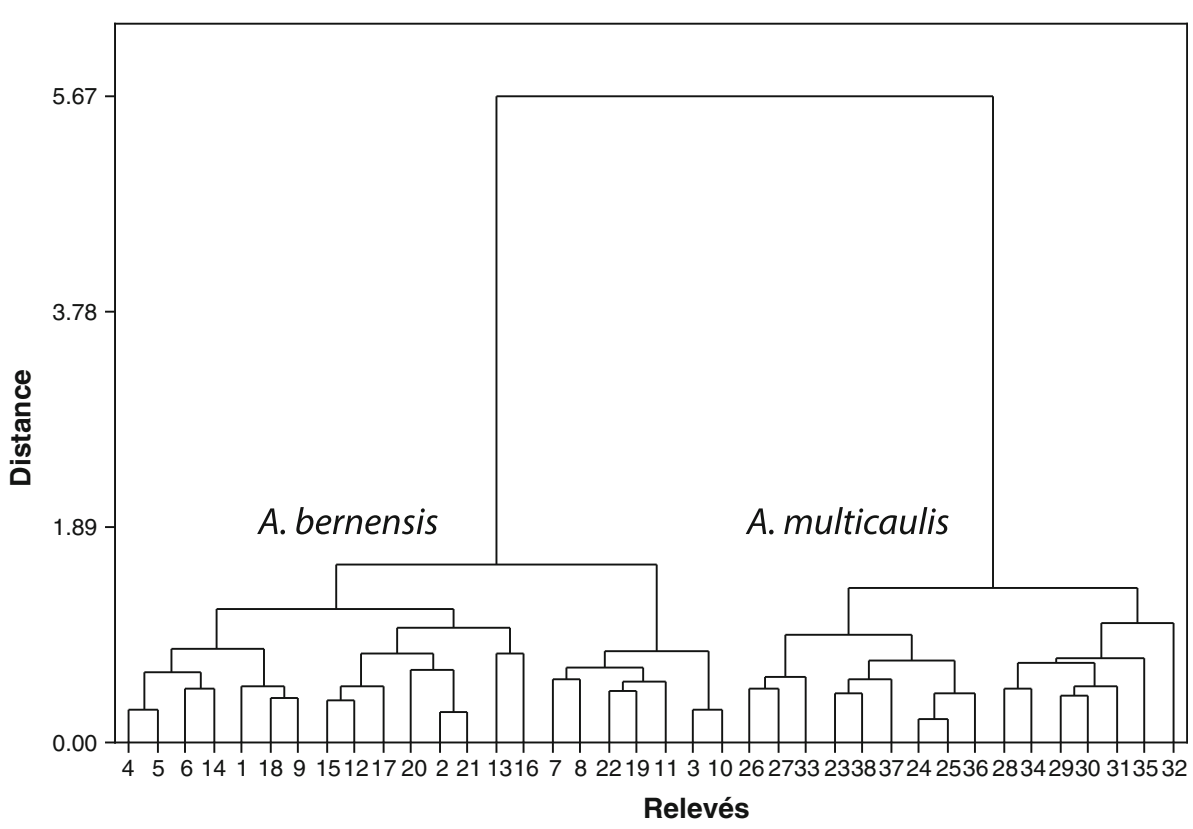


plus Dent de Brenleire) and clade 2b (plants from locus classicus plus Kaisereggpass and Stockhorn).

Intraspecific genealogies and diversity

The median-joining (MJ) network emphasizes two highly divergent haplotype groups comprising a total of nine haplotypes (Fig. S1; Table S3). The first haplotype group (A) brings together haplotypes of $A$. bernensis, all specimens of $A$. multicaulis and the specimen of $A$. gothica from Lac de Joux. Group (B) comprises haplotype sequences of all $A$. ciliata s.str. and three haplotypes of specimens attributed to

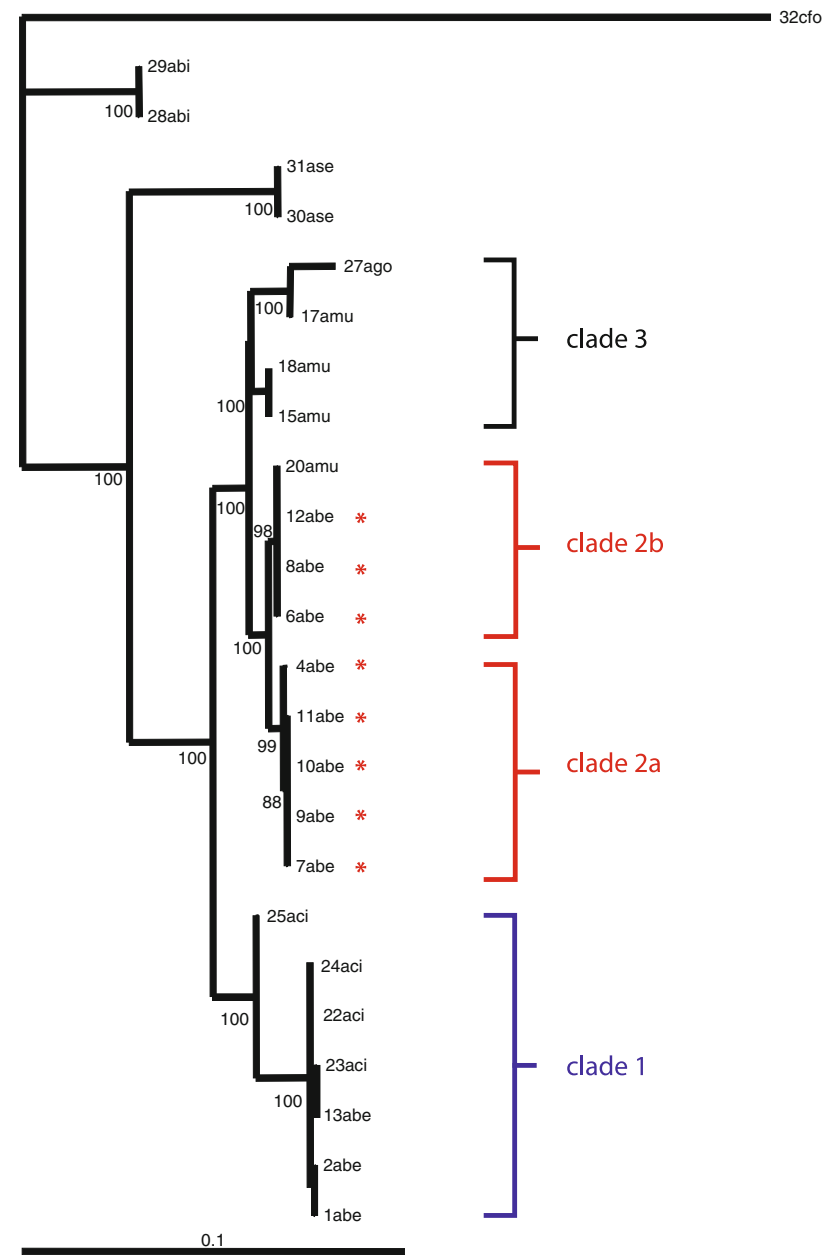

Fig. 5 Parsimony tree of sampled specimens from the A. ciliata complex based on cpDNA sequence data. Clade 1 includes specimens of A. ciliata s.str. with three specimens attributed morphologically to A. bernensis. Clade 2 includes the core A. bernensis from the locus classicus and all populations with irregular floral morphology. It is further divided into clade $2 a$ (plants from locus classicus plus Dent de Brenleire) and clade $2 b$ (plants from locus classicus plus Kaisereggpass and Stockhorn). Clade 3 comprises individuals of $A$. gothica and A. multicaulis. Asterisks indicate individuals from populations where plants with irregular flowers were observed. Bootstrap support percentages $>65 \%$ are indicated along the nodes. For the explanations of symbols of sampled individuals, see Table 2
A. bernensis in the morphological determination: 1abe (Dent de Lys, FR), 2abe (Pointe de Paray, FR) and 13abe (Klosterwappen from Wiener Schneeberg, Austria). A total of 31 polymorphic sites were found for the narrowly endemic $A$. bernensis, resulting in five different cpDNA haplotypes, and nucleotide diversity was $0.0084( \pm 0.0034 \mathrm{SD})$.

\section{Discussion}

Life on an archipelago

Arenaria bernensis - as other Swiss alpine plant endemics (e.g., Artemisia nivalis and Draba ladina)—has a very small range with a restricted number of populations (Widmer and Baltisberger 1999; Aeschimann et al. 2011). In fact, its distribution area is composed of an archipelago of six peripheral summits isolated from each other by distances of 5-10 km. Furthermore, A. bernensis is one of the rare taxa of the western Prealps occurring exclusively on cool, shady and steep slopes with northern exposition, in the vicinity of crests and summits, typically above 1,900-2,000 m a.s.1. Interestingly, A. bernensis flowers very late, often in September and frequently after the first snow fall (Favarger 1963; Richard 1977). This unique specialization accompanied by its restricted distribution area and the very small number of populations and individuals makes $A$. bernensis a potential candidate for extinction due to forecasted global warming. Thus, prealpine narrow endemics, such as A. bernensis, are of great importance for understanding the effect of global change on ecosystems in the peripheral Alps and merit further research efforts and a special conservation status (Eggenberg and Landolt 2006).

The explicit differentiation between relevés of $A$. bernensis and A. multicaulis presented in our study underpins the particular status of A. bernensis. Richard (1977), analyzing relevés from Vallon des Morteys and Schopfenspitz (FR), described a new plant community with A. bernensis (Arenario-Salicetum reticulatae Richard 1977) and proposed to place it within the alliances of the alpine meadows (e.g., Caricion firmae or Elynion). However, the presence of species such as Salix reticulata (Table S1; Fig. S2) and $S$. retusa indicates strong affinities of $A$. bernensis with the vegetation of snowbeds (e.g., alliance Arabidion caeruleae) (Delarze and Gonseth 2008). The precise phytosociological classification of $A$. bernensis and its communities needs, therefore, more research and in-depth analysis, and exceeds the scope of the present contribution.

Phylogeny of the A. ciliata aggregate

Results of our study confirm that the A. ciliata aggregate is a monophyletic group (including A. ciliata s.str., 
A. multicaulis, A. gothica and A. bernensis). Arenaria gothica, an endemic taxon of Lac de Joux (Halliday 1960a, b; Delarze et al. 2004) never studied genetically before, clusters with A. multicaulis. This outcome corroborates the biometric research of Wyse Jackson and Parnell (1987), thus supporting the affiliation of A. gothica to A. multicaulis. However, A. gothica carries a unique haplotype (Fig. S1; Table S3) and thus appears to represent a distinct taxonomic units.

Furthermore, both the gene tree and the network emphasize that A. multicaulis and A. ciliata s.str. do not share closely related haplotypes (Figs. 5; S1; Table S3). Previous studies even proposed to remove A. multicaulis from the A. ciliata complex. The hypothesis was based on cytotaxonomic studies of Favarger (1965) and was additionally supported by biometric research (Wyse Jackson and Parnell 1987). Our present molecular study does not support this view and the removal of A. multicaulis from the aggregate is not justified. However, our results demonstrate that the $A$. ciliata complex contains two distinct groups: one with A. multicaulis, A. gothica and A. bernensis and the second with A. ciliata s.str. (Figs. 5; S1).

Although no final conclusion about the taxonomic status of A. bernensis should be drawn in the absence of nuclear DNA data, we propose that populations enclosed between the north of Vanil Noir (FR) and Stockhorn (BE) should be treated as a separate conservation unit (populations marked with red circles in Fig. 2). The irregular floral phenotypes and distinctive ecology of plants occurring in all these populations additionally support their special status.

Independently of the taxonomic status of A. bernensis itself, our study suggests close affiliation of plants from clades $2 \mathrm{a}$ and $2 \mathrm{~b}$ to A. multicaulis (both the median-joining network and the Parsimony tree, Figs. 5; S1) and not to A. ciliata s.str. If confirmed with nuclear markers, this could have important consequences for the Swiss floristic records. First, the merging of A. bernensis into A. ciliata s.str. and its use as a synonym in the recent literature (e.g., in Aeschimann et al. 2004; Aeschimann and Heitz 2005) should then be changed. Second, the existing distribution map including A. bernensis occurrences between Vanil Noir and Stockhorn into A. ciliata s.str. would need to be revised (at http://www. infoflora.ch).

High polyploidy, high genetic diversity and enigmatic history of A. bernensis

The key to interpret the phylogeographic and biogeographic history of A. bernensis may lie in its high polyploidy level, as already hypothesized by Favarger in the 1960s (Favarger 1960, 1963, 1965). This ploidy of A. bernensis (dodecaploid, $2 n=240$ ) may also be responsible for its unusual morphological traits compared to other members of the A. ciliata complex (very large petals and multiplication of floral elements, Figs. 1; S2). According to Favarger, this high ploidy level may result from an allopolyploid speciation event involving A. multicaulis and another relative (perhaps one that has disappeared from the western Prealps at the present time). Considering the geographical position of A. bernensis in relation to A. multicaulis and A. ciliata s.str., a hybrid origin involving these last two species is probable. Nevertheless, since the cpDNA genome is transmitted only through the maternal line, current phylogenetic evidence is limited. Thus, future investigations should build on nuclear genomic DNA to delimit more precisely the genetic relationships within the A. ciliata complex. Another surprising finding of our study refers to the relatively high genetic diversity found in A. bernensis. Some cpDNA phylogeographic studies do not recover that much diversity on such small spatial scales. Westergaard et al. (2011), for example, recovered fewer polymorphisms in an arctic Arenaria species at a much wider sampling scale. We suggest two possible hypotheses to explain this high level of genetic diversity in A. bernensis. Firstly, as the boundaries between the species are not well delimited at the current time, it is possible that inclusion of specimens from other taxa (e.g., A. multicaulis or A. ciliata s.str.) may have inflated our estimates of diversity. Secondly, elevated diversity in A. bernensis may point to the presence of a peripheral refuge of A. bernensis in the western Prealps during the Pleistocene glaciations, sometimes referred to as nunatak survival.

Apparently, A. bernensis is very diverse and has a complex evolutionary history. Future investigation of nuclear genomic DNA is clearly needed to clarify the taxonomic position of A. bernensis among other members of the A. ciliata complex. To avoid problems with misidentification during future work, we recommend cytotaxonomic studies in parallel to molecular systematics work.

Acknowledgments We would like to thank Benoît Clement, Susanne Bollinger and Françoise Cudré-Mauroux from the Botanical Garden of the University of Fribourg (Switzerland); André Fasel and Emanuel Gerber from the Natural History Museum in Fribourg (NHMF, Switzerland); as well as Marius Achermann and Francesca Cheda from the Nature Protection Office of the Canton Fribourg (Switzerland) for their advice, financial and technical support as well as Pro Natura Fribourg for the permissions. Special thanks go to Martina Löwy (http://www.loewy-illustration.ch) for her engagement in the Arenaria bernensis project.

\section{References}

Aeschimann D, Heitz C (2005) Index synonymique de la Flore de Suisse et territoires limitrophes (ISFS). Documenta floristicae helvetiae, Geneva

Aeschimann D, Lauber K, Moser D, Theurillat J (2004) Flora alpina, vol 3. Haupt, Bern 
Aeschimann D, Rasolofo N, Theurillat J-P (2011) Analyse de la flore des Alpes. 1: historique et biodiversité. Candollea 66:27-55

Bandelt H-J, Forster P, Roehl A (1999) Median-joining networks for inferring intraspecific phylogenies. Mol Biol Evol 16:37-48

Becherer A (1972) Führer durch die Flora der Schweiz. Schwabe \& Co., Basel

Bouxin G (1986) Le traitement statistique des tableaux de relevés de végétation. 1. Les petits tableaux. Biométrie-Praximétrie 26: 49-72

Brun-Hol (2007) Campanula excisa-ein zierlicher Alpenpionier in steter Bedrängnis. Bauhinia 20:57-69

Caron C (1973) Survol géologique des Alpes occidentales. Bull Soc Frib Sci Nat 62:73-81

Delarze R, Gonseth Y (2008) Lebensräume der Schweiz. ÖkologieGefährdung-Kennarten. Hep Velag, Bern

Delarze R, Druart P, Kozlowski G, Moret J-L, Prunier P, Gmür P (2004) Arenaria gothica et autres plantes rares des rives lacustres de la Vallée de Joux (Vaud, Suisse). Quelques observations récentes et premières données autoécologiques. Bull Soc Vaud Sci Nat 89:1-11

Eggenberg S, Landolt E (2006) Für welche Pflanzenarten hat die Schweiz eine internationale Verantwortung? Bot Helv 116: 119-133

Favarger C (1960) Recherches cytotaxonomiques sur les populations alpines d'Arenaria ciliata L. (sens. lat.). Bull Soc Bot Suisse 70:126-140

Favarger C (1963) Nouvelles recherches sur les populations alpines et carpathiques d'Arenaria ciliata L. sens. lat. Bull Soc Bot Suisse 73:161-178

Favarger C (1965) A striking polyploid complex in the alpine flora: Arenaria ciliata L. Bot Notiser 118:273-280

Favarger C, Contandriopoulos J (1961) Essai sur l'endémisme. Bull Soc Bot Suisse 71:384-408

Gerber E, Kozlowski G, Mariéthoz A-S (2010) La flore des Préalpes du lac de Thun au Léman. Rossolis, Bussigny

Gilomen H (1941) Die Flora der westschweizerischen Kalkvoralpen. Sonderabdruck aus den Mitteilungen der Naturforschenden Gesellschaft in Bern. Haupt, Bern

Halliday G (1960a) Taxonomic and ecological studies in the Arenaria ciliata and Minuartia verna complexes. $\mathrm{PhD}$ thesis. Camhridge University

Halliday G (1960b) The identity of Arenaria gothica auct. angl. Watsonia 4:207-210

Landolt E (2006) Zur Kenntnis der Taxonomie und Verbreitung der Alpenpflanzen. Bot Helv 116:79-90

Lauber K, Wagner G, Gygax A, Aeschimann D (2012) Flora Helvetica. Haupt, Bern

Naciri Y, Gaudeul M (2007) Phylogeography of the endangered Eryngium alpinum L. (Apiaceae) in the European Alps. Mol Ecol 16:2721-2733

Naciri Y, Cavat F, Jeanmonod D (2010) Silene patula (Siphonomorpha, Caryophyllaceae) in North Africa: a test of colonisation routes using chloroplast markers. Mol Phylogenet Evol 54: 922-932

Ozenda P (2002) Perspectives pour une géobiologie des montagnes. Presses polytechniques et universitaires romandes, Lausanne

Parisod C (2008) Postglacial recolonisation of plants in the western Alps of Switzerland. Bot Helv 118:1-12

Parisod C, Besnard G (2007) Glacial in situ survival in the western Alps and polytopic autopolyploidy in Biscutella laevigata L. (Brassicaceae). Mol Ecol 16:2755-2767

Poore M (1955a) The use of phytosociological methods in ecological investigations: I. The Braun-Blanquet system. J Ecol 43:226-244

Poore M (1955b) The use of phytosociological methods in ecological investigations: II. Practical issues involved in an attempt to apply the Braun-Blanquet system. J Ecol 43:245-269

Richard J-L (1977) La végétation du Vanil Noir et du Vallon des Morteys. Bull Soc Frib Sc Nat 66:1-52

Ronquist F, Huelsenbeck J, Maxim T (2011) MrBayes version 3.2 manual: tutorials and model summaries (online publication)

Salzburger W, Ewing GB, von Haeseler A (2011) The performance of phylogenetic algorithms in estimating haplotype genealogies with migration. Mol Ecol 20:1952-1963

Scarcelli N, Barnaud A, Eiserhardt W, Treier UA, Seveno M, d'Anfray A, Vigourox Y, Pintaud J-C (2011) A set of 100 chloroplast DNA primer pairs to study population genetics and phylogeny in monocotyledons. PLoS ONE 6:e19954. doi: 10.1371/journal.pone.0019954

Schönswetter P, Stehlik I, Holderegger R, Tribsch A (2005) Molecular evidence for glacial refugia of mountain plants in the European Alps. Mol Ecol 14:3547-3555

Shaw J, Lickey EB, Beck JT, Farmer SB, Liu W, Miller J, Siripun KC, Winder CT, Schilling EE, Small RL (2005) The tortoise and the hare II: relative utility of 21 noncoding chloroplast DNA sequences for phylogenetic analysis. Am J Bot 92:142-166

Shaw J, Lickey EB, Schilling EE, Small RL (2007) Comparison of whole chloroplast genome sequences to choose noncoding regions for phylogenetic studies in angiosperms: the tortoise and the hare III. Am J Bot 94:275-288

Stehlik I (2000) Nunataks and peripheral refugia for alpine plants during quaternary glaciation in the middle part of the Alps. Bot Helv 110:25-30

Taberlet P, Gielly L, Pautou G, Bouvet J (1991) Universal primers for amplification of three non-coding regions of chloroplast DNA. Plant Mol Biol 17:1105-1109

Westergaard KB, Alsos IG, Popp M, Engelskjøn T, Flatberg KI, Brochmann C (2011) Glacial survival may matter after all: nunatak signatures in the rare European populations of two westarctic species. Mol Ecol 20:376-393

Widmer A, Baltisberger M (1999) Molecular evidence for allopolyploid speciation and a single origin of the narrow endemic Draba ladina (Brassicaceae). Am J Bot 86:1282-1289

Wyse Jackson M, Parnell J (1987) A biometric study of the Arenaria ciliata L. complex (Caryophyllaceae). Watsonia 16:373-382 